\title{
Article \\ Geomorphological Hazard in Active Tectonics Area: Study Cases from Sibillini Mountains Thrust System (Central Apennines)
}

\author{
Domenico Aringoli ${ }^{1, *}$, Piero Farabollini ${ }^{1}{ }^{\circledR}$, Gilberto Pambianchi $^{1}$, Marco Materazzi ${ }^{1}\left(\mathbb{C}\right.$, Margherita Bufalini ${ }^{1}(\mathbb{D}$, \\ Emy Fuffa ${ }^{1}{ }^{\circ}$, Matteo Gentilucci ${ }^{1}\left(\mathbb{D}\right.$ and Gianni Scalella ${ }^{2}$ \\ 1 School of Sciences and Technology, Geology Division, University of Camerino, Viale Gentile III da Varano, 7 , \\ 62032 Camerino, Italy; piero.farabollini@unicam.it (P.F.); gilberto.pambianchi@unicam.it (G.P.); \\ marco.materazzi@unicam.it (M.M.); margherita.bufalini@unicam.it (M.B.); emy.fuffa@unicam.it (E.F.); \\ matteo.gentilucci@unicam.it (M.G.) \\ 2 Office of the Extraordinary Commissary for Central Italy Earthquake 2016, via della Ferratella in Laterano, 51, \\ 00184 Rome, Italy; gianni.scalella@regione.marche.it \\ * Correspondence: domenico.aringoli@unicam.it
}

check for updates

Citation: Aringoli, D.; Farabollini, P.; Pambianchi, G.; Materazzi, M.; Bufalini, M.; Fuffa, E.; Gentilucci, M.; Scalella, G. Geomorphological Hazard in Active Tectonics Area: Study Cases from Sibillini Mountains Thrust System (Central Apennines). Land 2021, 10, 510. https://doi.org/ 10.3390/land 10050510

Academic Editor: Oren Ackermann

Received: 28 March 2021

Accepted: 7 May 2021

Published: 11 May 2021

Publisher's Note: MDPI stays neutral with regard to jurisdictional claims in published maps and institutional affiliations.

Copyright: (c) 2021 by the authors. Licensee MDPI, Basel, Switzerland. This article is an open access article distributed under the terms and conditions of the Creative Commons Attribution (CC BY) license (https:// creativecommons.org/licenses/by/ $4.0 /)$.

\begin{abstract}
In many areas of the Umbria-Marche Apennines, evident traces of huge landslides have been recognized; these probably occurred in the Upper Pleistocene and are conditioned by the tectonic-structural setting of the involved Meso-Cenozoic formations, in a sector of the Sibillini Mountains (central Italy). The present work aimed to focus on a geomorphological hazard in the tectonic-structural setting of a complex area that is the basis of several gravitational occurrences in different types and mechanisms, but nonetheless with very considerable extension and total destabilized volume. An aerophoto-geological analysis and geomorphological survey allowed verification of how the main predisposing factor of these phenomena is connected with the presence in depth of an important tectonic-structural element: the plane of the Sibillini Mountains thrust, which brings the pre-evaporitic member of the Laga Formation in contact with the Cretaceous-Eocene limestone lithotypes (from the Maiolica to the Scaglia Rosata Formations) of the Umbria-Marche sedimentary sequence. Another important element for the mass movements activation is the presence of an important and vast water table and related aquifer, confined prevalently by the different structural elements and in particular by the thrust plane, which has acted and has continued to act, weakening the rocky masses and the overlaying terrains.
\end{abstract}

Keywords: large-scale landslides; DSGSDs; normal faults and overthrusts; Sibillini Mts.; Central Apennines

\section{Introduction}

The Central Apennines (Italy) is a young and tectonically active mountain range characterized by a high structural complexity. The single structures related to the different tectonic phases interact with each other, favoring the reactivation of the old ones or leading to the segmentation of the recently formed ones. The result is a strong stress, both on the seismic characteristics of the area and on the geomorphological evolution of the Apennine reliefs, especially those characterized by the presence of important tectonic elements. In general, it is accepted that tectonics can play a dual role in influencing the gravitational evolution of the slopes: (i) a passive role, related to the influence on the structural setting of the slopes, which can be inherited from a tectonic phase no longer active; and (ii) an active role, represented by the changes that it can determine on the slopes, producing increases in the relief energy and tensional stress suffered by the rock volumes [1].

In this perspective, a study was carried out on the southern slopes of the Sibillini Mountains ridge in correspondence with the area most affected by the recent seismic 
sequence where, through detailed geological and geomorphological surveys, several large landslides and deep-seated gravitational slope deformations (DSGSDs) have been mapped.

Analyses and kinematic verifications allow us to hypothesize an important correlation both with the present tectonic structures and with the hydrogeological characteristics of the rocky masses and the contained aquifers, in analogy with what has already been verified in other areas of the Alps and of the Apennines chain [1-10] or in other areas of the Earth's surface on various mountain ridges, such as Bethic Belt, Carpathian Belt, Tien Shan Mountains, Pamir Mountains, and Williams Range in Colorado [11-18].

The present work therefore aims to highlight how the combination of the abovementioned factors is fundamental in many gravitational processes ranging from large mass movements to huge landslides and to DSGSD sensu [2], as well as in more superficial phenomena and in "classical" ones [19].

The relationship between active tectonics and DSGSDs and/or large landslides along the tectonic slopes of the Sibillini Mountains also plays an extremely important role in differentiating the risk associated with seismic and/or hydrogeological events occurring in the area.

\section{Data and Methods}

\subsection{Geological and Structural Setting}

In the area outcrops the typical Umbria-Marche Succession, a sedimentary sequence consisting of a stratified sedimentary succession of pelagic environment, in which calcareous and marly-calcareous lithotypes alternate with siliceous ones (Figure 1). This succession is set on massive limestones, disjointed by an extensional tectonic phase in the Middle Lias. This situation gave rise both to the deposition of a complete succession, characterized by considerable thicknesses, and to the deposition of reduced/condensed succession, characterized by considerable variations in thickness and with singular lithological features [20-22].

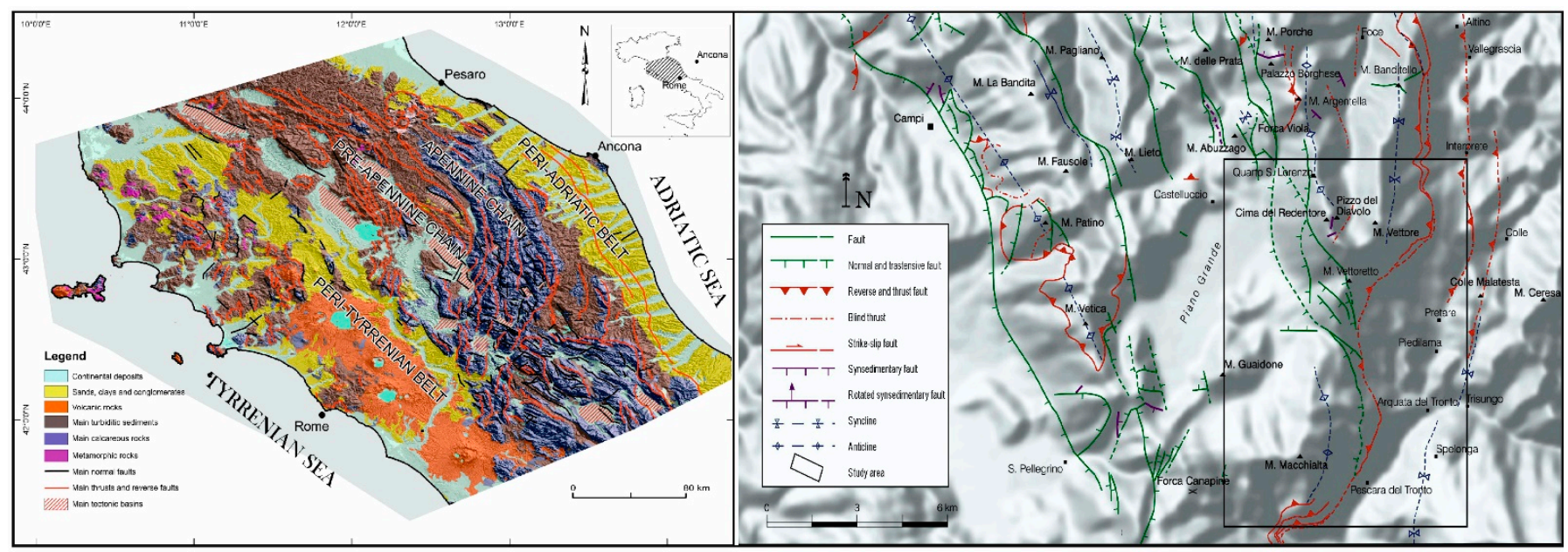

Figure 1. Geological and structural sketch of the Sibillini Mountains area.

The typical structural arrangement is that of thrusts and folds chain with a prevalently eastern vergence, with axes in approximately N-S direction (Figure 1). The tectonic movement that gave rise to the relief has produced a series of overthrusts and inverse faults, very evident on the eastern flanks of the anticlines, which caused the shortening and overlapping of older terms on more recent deposits. The main structural element that delimits to the east the carbonatic ridge is the Sibillini Mountains thrust, which extends southward until it joins the "Ancona-Anzio Line" [23-25].

The structure of the thrust front is characterized by a northeastern arched geometry and Adriatic convexity; in the northern part the trend is "apenninic" (NNW-SSE), while in the southern part it is approximately N-S. This regional tectonic style presents a complex 
articulation: in some areas it is realized through a main single surface, while in others through two intersecting surfaces delimiting an intermediate body more advanced than the lower one but more backward than the upper one [24,26,27].

The Sibillini Mts. thrust brought the internal Meso-Cenozoic formations on the more external Cretaceous-Paleogenic terms in the northern sector with respect to the Aso River and on essentially Miocene formations in the southern sector (Figure 2). This compressive style, which delimits the carbonatic ridge, is followed by extensional tectonics, whose disjunctive faults have profoundly modified the original stratigraphic structure [28]. This extensional phase then gave rise to the intermontane depressions (Castelluccio di Norcia, Norcia, Cascia, etc.; Figure 1) filled by quaternary continental sediments, characterized by lacustrine and alluvial deposition since the Pliocene $[25,29,30]$. At the southwestern edge of the study area, a set of compressive tectonic lines, with Apennine direction and northeastern vergence, produced an intense deformation of the different lithotypes, so much so as to totally alter their original hydrogeological characteristics: in fact, locally has been formed a hydraulic barrier, separating the considered area from the adjacent ones.
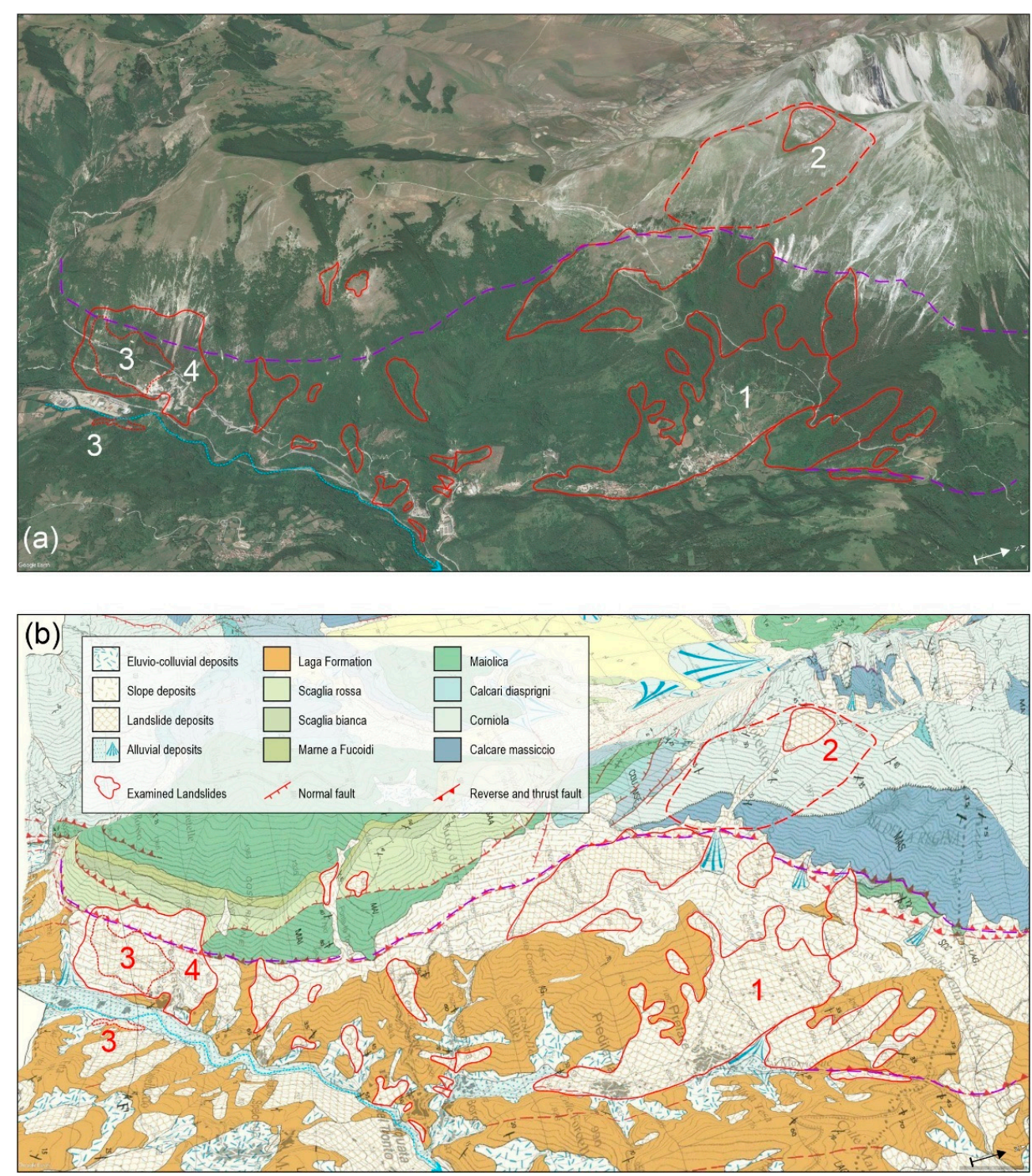

Figure 2. Three-dimensional physiographic schemes of the study area (a) (source Google Earth) and corresponding geological sketch (b) (after [28], modified). The numbers refer to the gravitational phenomena described in the text: 1, Pretare-Piedilama; 2, Mount Vettoretto; 3 and 4, Pescara del Tronto. 
The persistence of the extensional activity in the Apennines is documented in several papers on active tectonics and paleoseismology [31,32] and by the occurrence of earthquakes with $\mathrm{M} \geq 6$, the last of which occurred in 2016 .

\subsection{Geomorphological Phenomena and Evolution}

The geomorphological structure of the area results from the action of morphogenetic processes that have shaped and still shape the region, strongly conditioned by several factors interacting each other: (i) the litho-structural and geomechanical characteristics of the bedrock that have exercised an important control over the morphological structure of slopes and valley floors, favoring the activation of gravitational phenomena in different types and sizes, directly conditioning the setting of drainage networks; (ii) Plio-Quaternary tectonics and up-lift, which have affected the Apennine belt since the Upper Miocene (in correspondence with the main tectonic phase of the chain) and, subsequently, in the Quaternary (starting from the end of the Lower Pleistocene) and testified by the strong seismicity of the area; (iii) the Quaternary climatic variations there were in the area after its emergence, which occurred from the Upper Miocene, coinciding with the tectogenetic acme of the Apennine chain that has activated specific morphogenetic processes, such as those responsible for the formation of glacial masses (glacial processes) and the frost action in the ground (periglacial processes) and which control the rates of surface alteration, slope degradation, and debris production; and iv) human activity (agriculture, urbanization, water regulation, excavation of gravels from the riverbeds, etc.), which has represented and continues to represent one of the main morphogenesis factors responsible for the activation of erosion and accumulation processes, considerably faster and more intense than those due to natural causes [2,3,33-35].

Studies on the area and new research following the 2016 seismic events [28-31,36-39] have allowed us to establish how the gravity in the Apennines chain area has its main expression in the genesis of large landslides and DSGSD $[3,40,41]$. In fact, the gravitational morphogenesis is particularly evident on the eastern slopes of the carbonatic ridges, along the folded sides of the structures and/or on the thrust fronts. Along these slopes can be observed steps, trenches, undulations, and fractures, together with large, sometimes rounded, landslide scarps; at the foot of the slopes, vast and thick debris deposits, sometimes coalescent, cover the more recent marly-clayey formations of the Umbria-Marche Succession. It has also been possible to identify important correlations between the morphometric and physiographic characteristics of the slopes and the geological structure of the reliefs $[6,42,43]$. The analysis of the morphometric and plano-altimetric characteristics of specific morphological elements (old planation surfaces, etc.), their "freshness", and their position with respect to the continental deposits has also allowed their chronological location and sometimes the understanding of their different evolutive stages. As regards the overall activity of the studied processes, considering the morphoclimatic context of the area and the position of the deposits on the slopes, it is possible to verify how almost all the processes are dormant $[10,39,44]$.

The largest landslides present in the study area (Figure 2) were connected to mixed kinematics and generally involved reactivation of ancient debris deposits or removal of thick landslide accumulations - in some cases, the same debris from slopes sutures of ancient landslide bodies that were resting on Miocene marly-clayey bedrock (e.g., palaeolandslide of Pescara del Tronto) $[6,10,39]$ were subsequently involved in new surficial reactivations.

In this stratigraphic framework, important instability elements are represented by the general hydrogeological setting and by the permeability of the lithotypes affected by gravity; this condition favors the activation of shear surfaces in the most clayey lithotypes with consequent passive transport of the overlying masses, sometimes even of several kilometers [6]. 


\section{Case Histories}

Along fault scarps and steep erosional slopes, deep-seated gravitational deformations and large-scale landslides, up to several square kilometers wide, may be observed. These phenomena are very common in the axial part of the Apennines (Figure 1), which was affected by strong uplift and extensional tectonics during the Late Quaternary. Therefore, the predisposing factors were identified not only in the recent tectonic uplift of the area, which determine high relief value, but also in the intense fracturing of the bedrock as well as in the presence of rigid rocky bodies overlying more plastic marly-clayey levels. Among the stratigraphic discontinuities, the pre-transgressive erosional surface plays a leading role because the main sliding surfaces coincide with it $[2,3,44,45]$.

Important deep-seated gravitational phenomena are surveyed in the Sibillini Mountains on the eastern side of the calcareous ridge, in particular along the eastern oversteepened sides of anticline fold and overthrust fronts [6,10,46]. Along these slopes, steps, trenches, undulations, and fractures may be observed, together with large-scale landslide scarps and wide debris deposits at the footslopes. These materials are often covered by Upper Pleistocene stratified slope-waste deposits, which sometimes are tilted counterslope.

The above phenomenologies are particularly diffused in the area between the calcareous and the turbiditic lithotypes, along the overthrust front of the Sibillini Mts. that, in the present case studies, emerge just above of the alignment of Pescara del Tronto-Arquata del Tronto towns (Figure 2). Below are the descriptions of some of the most important phenomena recognized and represented in the geomorphological scheme of Figure 2.

\subsection{The Pretare-Piedilama Landslides}

At the base of the eastern flank of Mount Vettore, on the SW of Mount Pianello della Macchia, there is a large landslide phenomenon, partly obliterated by thick slope debris and debris flow deposits (Figure 3), whose accumulation extends as far as the built-up area of Pretare and Piedilama. The two inhabited centers are in fact located on the accumulation of an ancient landslide with huge calcareous blocks, fed by the hanging wall of the Sibillini Mountains, which occupy the bottom of the Fosso di Morricone valley, engraved on the flysch of the Laga Formation.

From a structural point of view, the flysch sequence on the hydrographic left of the Morricone stream constitutes the western side of an anticline (Figure $3 a, b)$, roughly $\mathrm{N}$ $5-10^{\circ}$ E oriented, dipping to the East with inclinations generally higher than $60^{\circ}$. On the hydrographic right of the Morricone stream, the reverse side of a further anticline fold is exposed, with an axis approximately oriented like the one previously described with oriental vergence, which is connected to the buried overthrusts but whose continuation is immediately recognizable northward of Pretare, in the direction of Montegallo town. This tectonic-structural setting (cross-section in Figure 3b) makes the Morricone stream an asymmetrical valley, downcutted into the nucleus of the above-mentioned anticline, with a hydrographic side on the left steeper than the one on the right, originating a subsequent ortho-clinal valley [47] and representing an excellent example of geomorphological convergence with the fault slopes [48].

The wide and complex landslide phenomenon (Figure 2) [10] originates in fact at the base of the Mount Vettore slope, on the footwall of the Sibillini Mountains thrust; it extends for several kilometers along the slope up to the Tronto River, with different overlapping mechanisms, essentially related to the stratigraphic-bedding conditioning and to the physical-mechanical characteristics of the bedrock materials.

The oldest continental deposits are represented by chaotic accumulations of mainly carbonate materials, with sharp or poorly rounded edges, in a reddish sandy-silty matrix, with metric levels of locally cemented carbonatic levels, and containing heterometric blocks of carbonate nature. Generally, these deposits are covered by stratified slope waste deposits attributable to the Upper Pleistocene, sometimes tilted mountainward; the two units are locally interspersed, showing how the movement is rather ancient and has undergone successive reactivations $[1,3]$. 

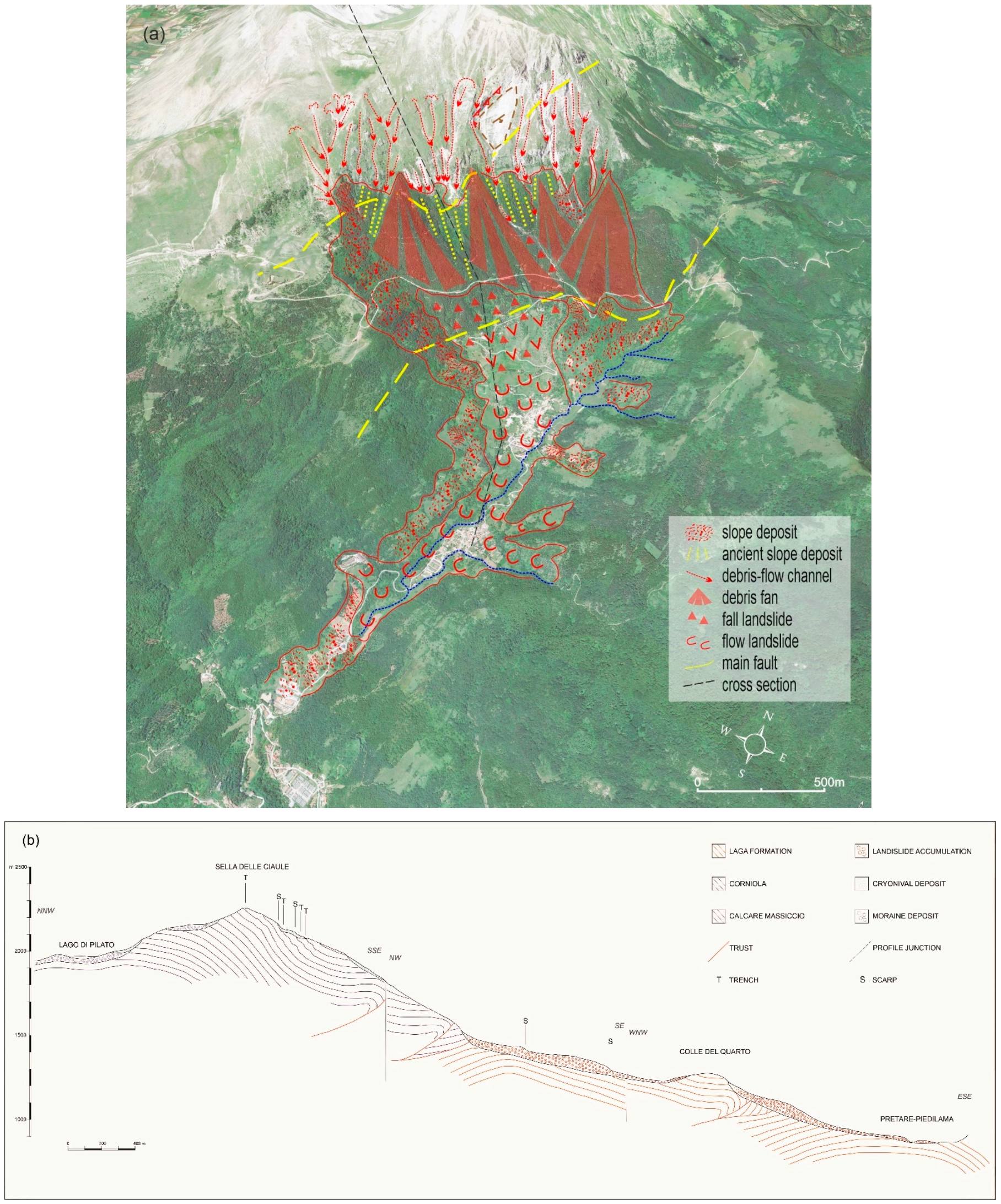

Figure 3. (a) Panoramic view of the southeastern slope of Mount Vettore area with the Pretare and Piedilama towns, which are found in the ancient and largest earthflow along the Morricone stream valley. (b) Geological and geomorphological schematic cross-section of the phenomena. 
The crown is rather irregular because the bedding of the Maiolica formation, which here verticalizes and overturns, has determined and continues to determine frequent collapsing and toppling phenomena (Figure 4); furthermore, the calcareous or marlycalcareous blocks and boulders are transported up to $4 \mathrm{~km}$ away from the origin. Along the whole southeastern side of the Mount Vettore-Il Pizzo alignment, in fact, extensive vertical escarpments, still fresh, with an articulated development, are in any case recognizable; this testifies to the repeated and continuous collapses, whose blocks and debris are recognizable at the foot of the slope, constituting an extensive debris layer given by coalescent cones, locally vegetated (Figures 2 and 4).

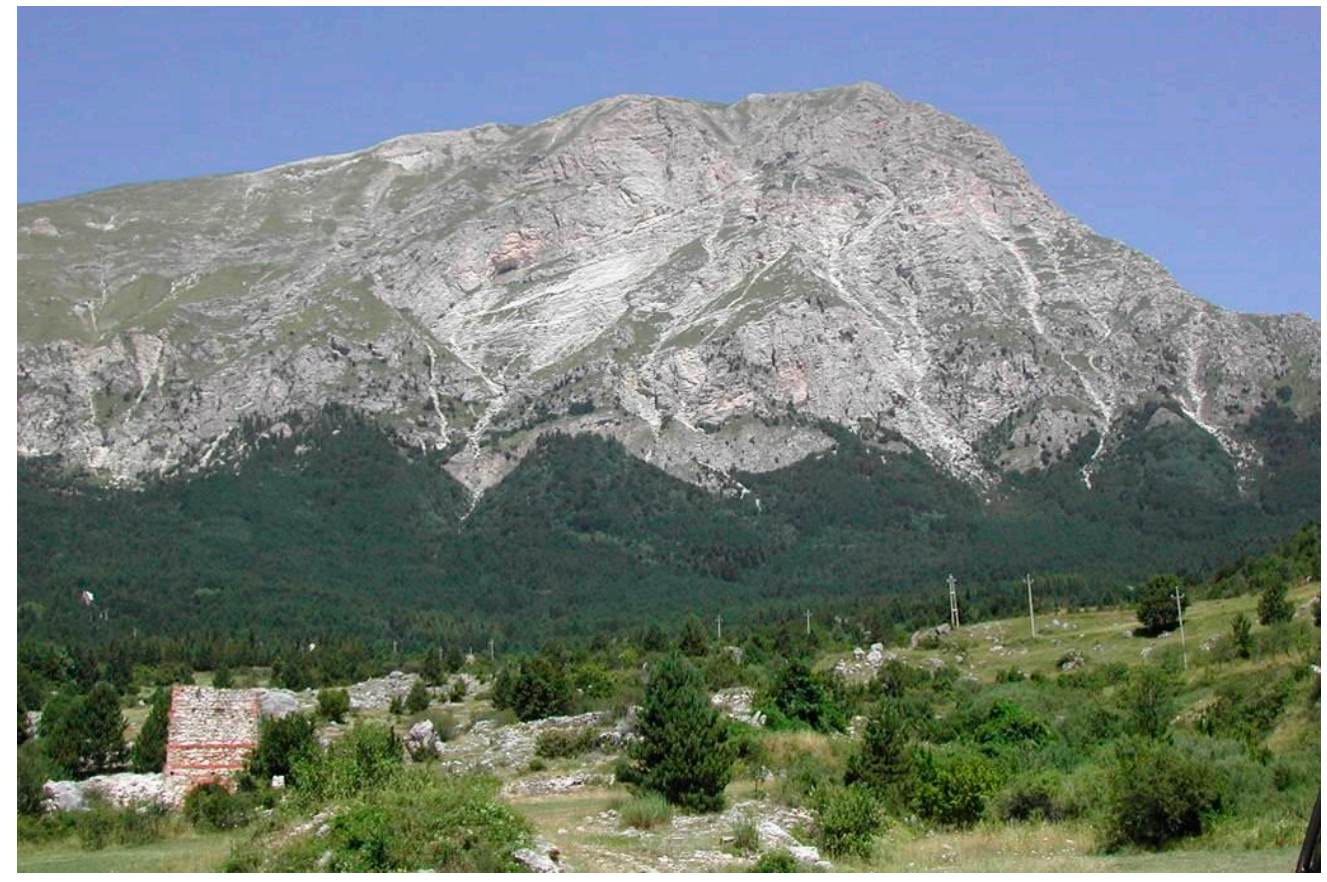

Figure 4. Southeastern slope of Mount Vettore. The decameter-sized blocks in front are related to the fall phenomena on this flank of the mount. In the top center, it is possible to recognize the scarp of one of the falls that occurred in the past, and at the foot of the slope, the extensive debris accumulation, completely vegetated, partially generated by debris flow processes and by fall landslides.

The large amount of debris accumulated at the foot of the slope, once the load limit has been reached, has triggered flows that were probably facilitated both by the bedding of the Laga Formation and by the sandy-clayey deposits resulting from the alteration of the above formation. The medium-terminal portion of the landslide body, which from the III level seismic microzonation investigations was estimated to be about $30 \mathrm{~m}$ thick $[49,50]$, was channeled into the valley of the Moricone stream due to the strong acclivity of the slope and evolved into a real landslide on which large blocks of Maiolica floated, like real rafts. The impressive tongues of boulders and amassed blocks, extended for several kilometers along the slope, are evidence of the passive transport operated by the casting phenomena generally set on the mostly marly-clayey lithotypes (Figure 3).

\subsection{The Mt Vettoretto DSGSD}

At the top of Mount Vettore, at about $2300 \mathrm{~m}$ above sea level, along the alignment of Punta di Prato Pulito-Mount Vettore, near the Zilioli hut, numerous trenches and ridge splits were observed (Figure 5); these are oriented about E-W, with lengths of over $100 \mathrm{~m}$ and widths of a few meters. Inside these depressions, more than one meter deep, partially filled with debris and soil, cracks and fractures of about $20 \mathrm{~cm}$ deep and $5 \mathrm{~cm}$ wide and free-face in rock are visible, denoting compaction following the seismic events of 2016. 


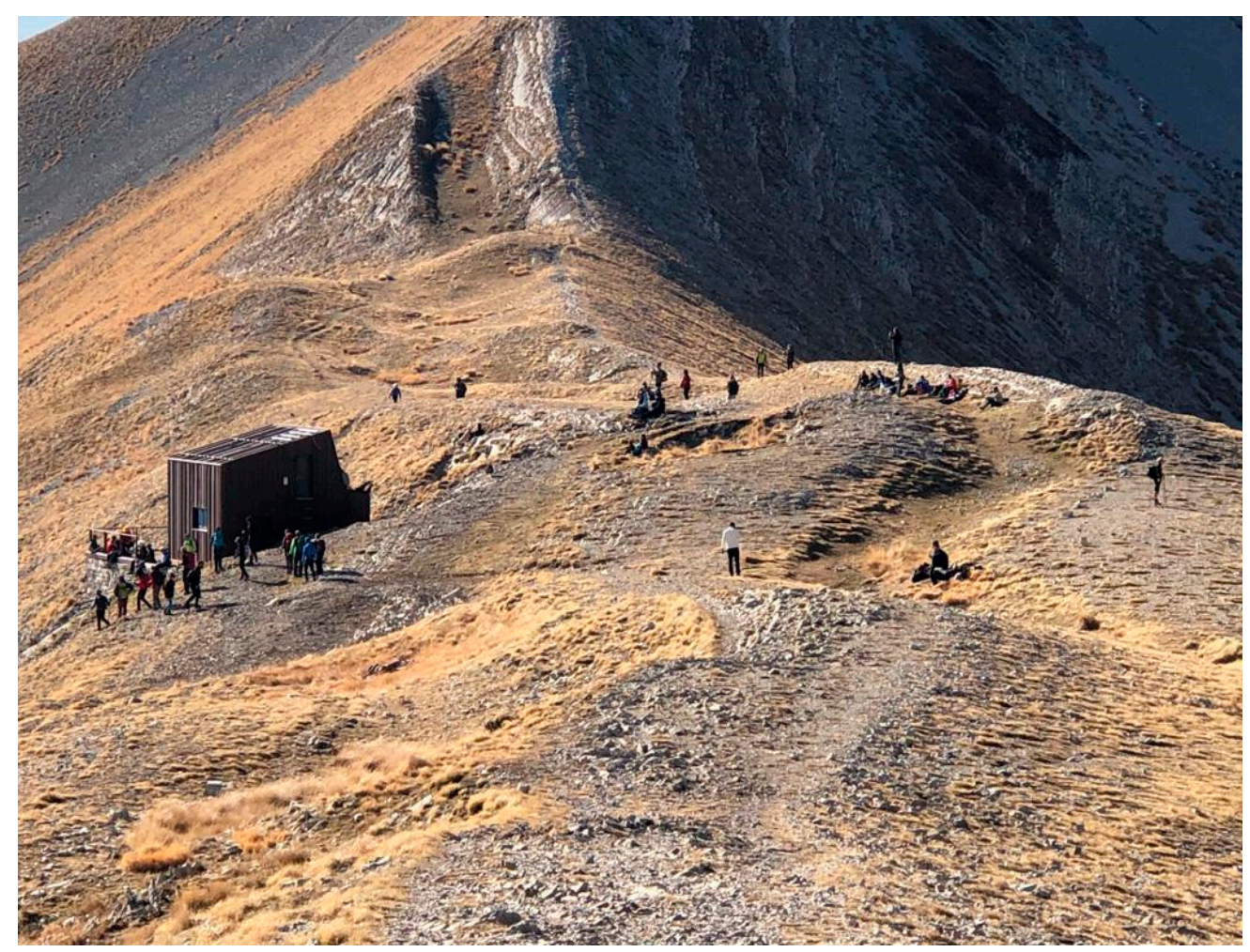

Figure 5. The upper part of the DSGSD with the trenches/double ridge near the Zilioli hut.

The southwestern slope of Mount Vettore is strongly deformed (Figure 6) and presents a morphology with a convex profile and small counter slopes, many of which are rounded and filled with soil and debris; the stratification along the slope, although the lithology is the same, presents undulations and micro folds, and the position changes with respect to the summit of the slope.

The above-mentioned morphological elements allow us to hypothesize the presence of a deep mass rock creep [51,52] whose evidences in the upper part of the slope can be masked by debris; the deformation could reach hundreds of meters. The genesis of the phenomenon can be attributed to the high relief energy due to the quaternary tectonic uplift, associated with the particular structural configuration of the area given by the interaction between the fault system of Mount Vettore and the Sibillini Mts. thrust (Figure 1).

These phenomena are generally set in depth $[2,3,53,54]$ along the most ductile levels of the stratigraphic sequence, while on the surface they are the same discontinuities in the rigid rocky masses created by the tectonics that guide them. The interferometric data allowed, even if with some doubt, indications of the possible kinematics of the deformation, allowing delineation of the complex tectono-gravitative scenario that has affected the area of Mount Vettore and has triggered the gravitational phenomenon [55]. In fact, triggering factors can be investigated, as moreover verified in similar situations in the Apennines area, in seismic events or in particular and extreme rainfall events [6]; nevertheless, even in Apennines areas at this altitude, the mentioned gravitational movements can also be associated with glacial decompression stresses [56].

The complex geological setting is characterized by the presence of two thrust planes close together, that overthrust, respectively, the oldest lithotypes of the "Sequence" (Calcare massiccio, Corniola, etc.) onto the more recent ones of (Scaglia formations), and these latter onto the pelitic-arenaceous association of the Laga Formation. In the area being examined, meso-structural analyses have evidenced a considerable reduction of the inclination of the thrust planes toward the west with respect to the characteristic values of the eastern front, which normally are around $30^{\circ}$. The calcareous lithotypes show an attitude that goes 
from subhorizontal to roughly dipping, the same as the slope. Locally, these lithotypes are covered by strongly cemented and stratified slope deposits.

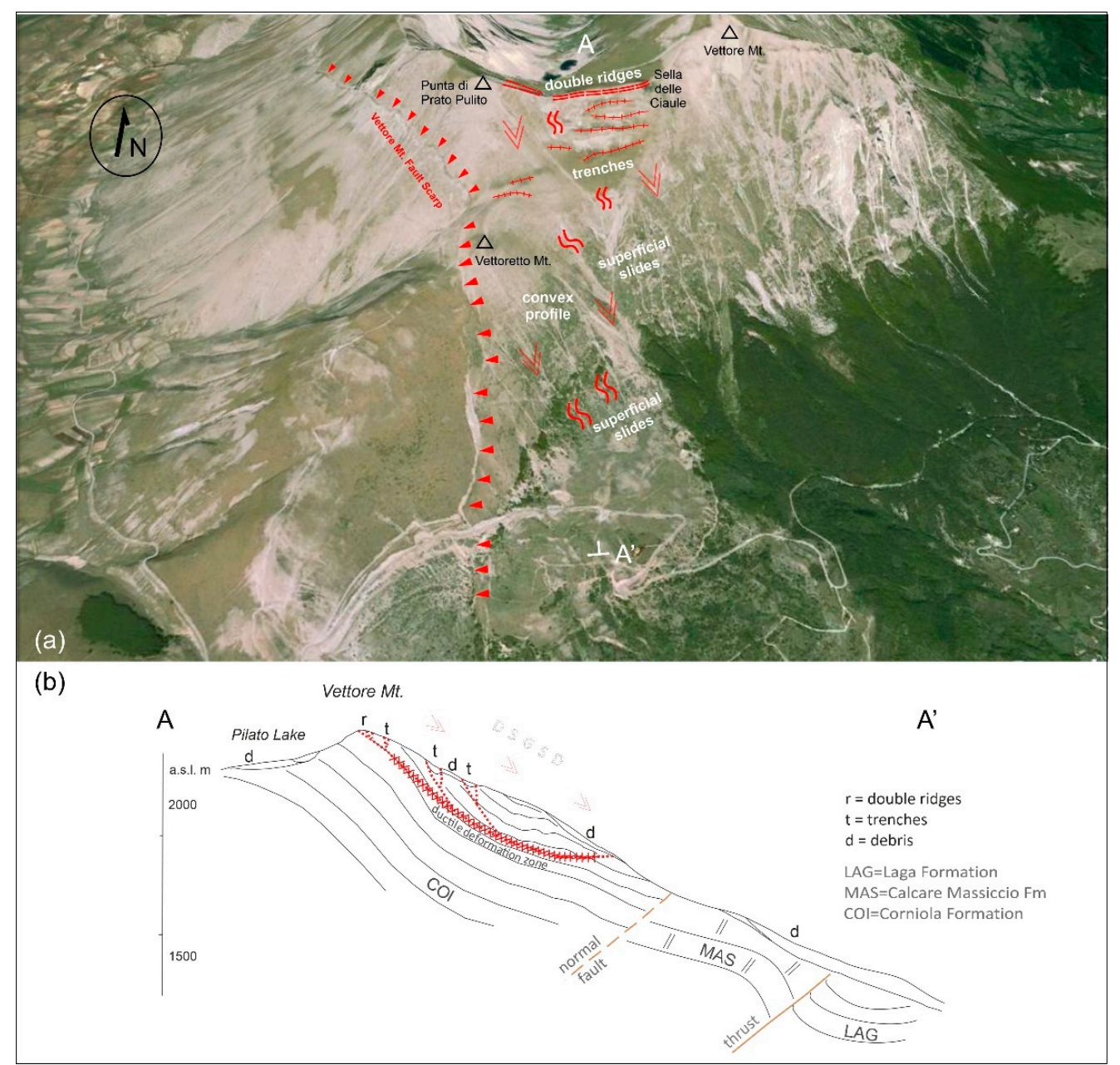

Figure 6. Panoramic view of the southwestern slope of Mount Vettore: (a) main geomorphological elements (source Google Earth); (b) schematic cross section (after [55], modified).

At the top of the slope (2000-2200 m a.s.1.), in the zone of the narrow watershed that divides it from the Pilato valley, modelled by the Pleistocene glaciation, it is possible to find trenches parallel to the direction of the watershed and that run along its entire length (double ridge). On the steep slope modelled in limestones beneath, certain landslide crowns can be recognized above which fissures, steps, trenches, undulations, and intense fracturing of the strata are present. These elements are ideally "joined" to each other by a linear scarp parallel to the slope and decimetric to metric in height. The more or less straight setting of the landform, though it is connected to polygenetic processes, allows us to hypothesize a tectonic control for its genesis, exerted by an extensive dislocation, without displacement, parallel to the slope.

The most evident landslide accumulations, where the attitude of bedrock is clearly visible, show evident rotation counterslopes in the zone of the crown and prevalent translations in the middle portion. Less extended fall phenomena also recur; their accumulations, at the foot, often evolve into debris-flows, which in turn evolve into alluvial fans. The "freshness" of all the elements permits us to associate the landforms along the calcareous slope with relatively "superficial" and recent gravitational phenomena. They are still in slow evolution, activated by roto-translational slides that take place, respectively, along the shear planes of neo-formation in the thickly stratified and subhorizontal rock masses and along shear planes predisposed by an attitude roughly dipping as the slope and by 
the presence of interspersed pelitic levels. The elevated frequency and density of these phenomena, anomalous with respect to that found in other sectors of the physiographic unit, allow us to hypothesize a control of the phenomena by a zone (or more than one zone) of ductile deformation. This would be predisposed by way of the probable listric geometry of the cited extensive tectonic dislocation, whose plane loses its own identity in the zone of intense tectonic fracturing between the two thrusts or in the marly levels below, which are even more ductile. On the basis of morphometric and structural considerations, these zones of deformation can be placed at a medium depth. A wider and deeper deformation, in addition, should have affected both the flank of the ridge in question, as is demonstrated by the presence of double crests. As a whole, it could fall within the category of the lateral spreads indicated by [19]. In more detail, a macrocambering phenomenon could affect the limestones of the eastern flank due to the differential dislocation realized in the pelitic-arenaceous lithotypes below the thrust, following strong weathering processes, squeezing out [57], and fluvial erosion. The phenomenon, in part associated with that described by [58] and by [59], is testified to by a considerable reduction of inclination of the thrust plane, connected, probably, to its deformation by gravity. Almost certainly, on the western flank the effects of the glacial decompression are felt.

\subsection{The Pescara del Tronto Landslide and the Tronto River Occlusion}

Studies carried out over a long time in the area $[2-4,10,39]$ have made it possible to verify how mass movements can create interference with river dynamics. One of the clearest and most impressive phenomena of this type is represented by the ancient movement of Pescara del Tronto, which involved enormous volumes of marly limestones and limited levels of terrigenous sediments. Only a part of the original accumulation, consisting of large masses of intensely fractured reddish limestone and gravels mixed with debris, is preserved on the hydrographic right of the Holocene plain of the Tronto River (Figure 7), while the detachment zone is located on the medium-low section of the slope on the hydrographic left $[6,10,39]$.

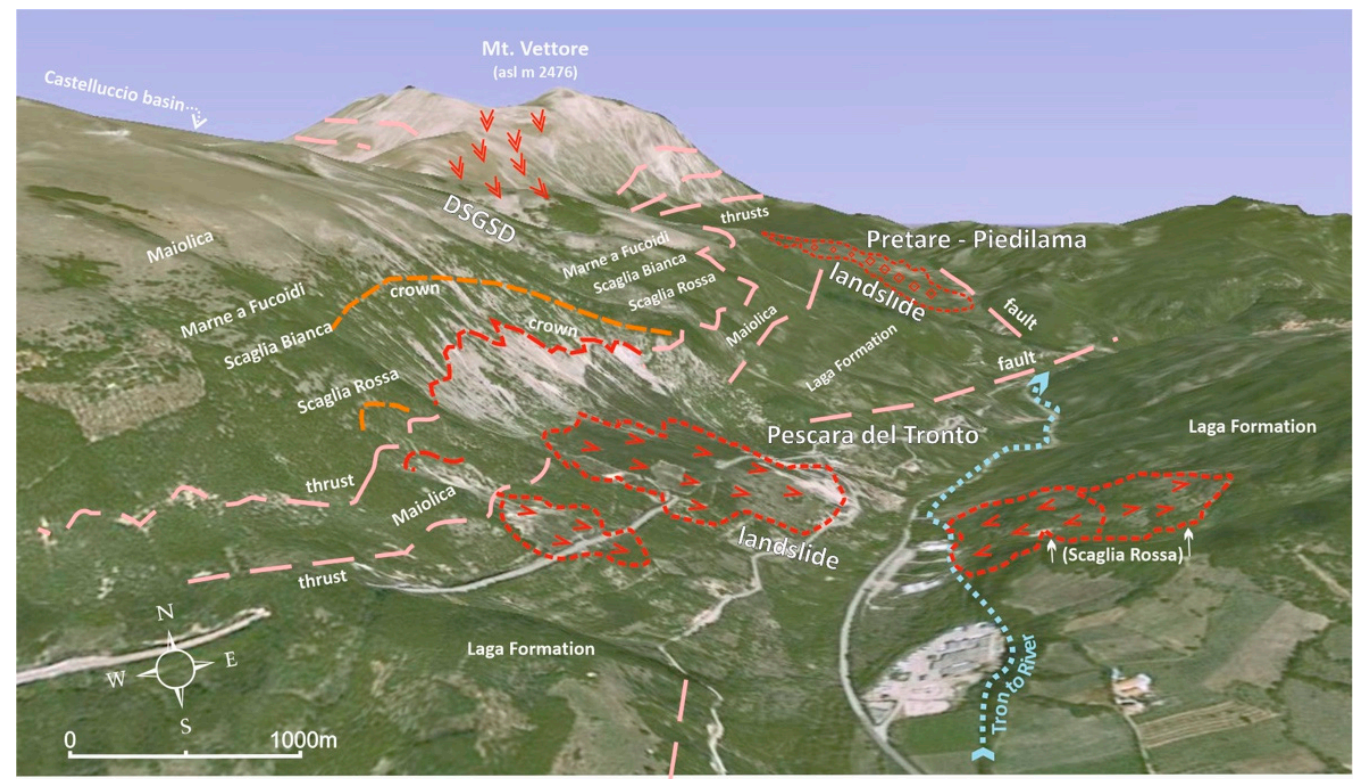

Figure 7. The topographic interpretative 3D scheme of the ancient landslide of Pescara del Tronto and, on the bottom, of the other analyzed phenomena (after [10], modified).

In this sector, the valley is narrow and deeply incised due to the convergence of the two mountain ridges: the calcareous one of the Sibillini Mountains and the turbiditic one of the Laga Mountains, oriented respectively NNE-SSW and NW-SE.

The welding of these two structures is realized through the great Sibillini thrust that overlaps the calcareous lithotypes onto the torbiditic ones. In this zone, a lateral contact 
must have also occurred between the two lithotypes along a roughly SW-NE alignment, as a result of a limited backthrusting. The backthrust, moreover, drove the Tronto River path in this portion of the valley; its incision, mainly connected to lower-middle Pleistocene tectonic uplifting, occurred into the arenaceous-pelitic lithotypes of the Laga formation. This is testified both by the strong asymmetry of the valley and by the lithological composition of the different generations of alluvial deposits, made up of mainly arenaceous pebbles and sandy-silty matrix.

Along the high slope on the hydrographic left, at a height of about $1000 \mathrm{~m}$. a.s.l., the mentioned thrust plane outcrops. In this zone it shows southeast verging and generally subhorizontal setting, which is interrupted by a modest upward concavity close to the builtup area of Pescara del Tronto. The geometric setting of the thrust plane and the contrasting hydrogeological characteristics of the involved lithotypes probably have caused a particular concentration of the water drained from the huge calcareous aquifer overlapped onto the turbiditic one.

Mountainward with respect to the Pescara del Tronto village, on the calcareous lithotypes, it is possible to observe a large landslide crown between the heights of 900 and 1150 $\mathrm{m}$ a.s.l. It seems to have been generated, given its articulated configuration, by the union of several gravitational phenomena [6,10,39], the evidence of which (benches, counterslopes, and high scarps) is still present along its slope. On the hydrographic right, detailed geotematic surveys developed on the valley bottom and at the foot of the slope, have evidenced, starting from the riverbed ( $660 \mathrm{~m}$ a.s.l.) up to a height of about $850 \mathrm{~m}$ a.s.l., the presence of a large calcareous "plate" made up mostly of the Scaglia Rossa Formation. It lays at the base and on the southern side on the arenaceous pelitic turbidites of the Laga Formation and in numerous outcroppings still has a well-preserved stratification. The base is an exception to this because it shows an intense fracturing (levels of "breccia"). The summit portion is partially covered by a landslide accumulation made up of turbidic lithotypes of the Laga Formation. The collocation in height of the upper portion of the "plate" is a bit above that of the end of middle Pleistocene (second order) alluvial deposit limbs, which outcrop on both sides of the river.

This presence, unique for the slope on the hydrographic right, is completely anomalous from a stratigraphic and structural point of view. In fact, on the hydrographic left, the same turbidite layers overthrusted due to the thrust plane onto the limestones of the Maiolica formation (1000 m a.s.l.), while the Scaglia Rossa outcrops about $200 \mathrm{~m}$ mountainward (at $1100 \mathrm{~m}$ a.s.l.). The data shown so far have a possible complete interpretation only through the hypothesis of a large mass movement that involved a much larger volume of material and whose calcareous plate represents a residual limb.

It is possible to schematize by four different steeps the complex kinematics of the phenomena (Figure 8a): the first stage corresponds to a rotational-translational slide that overlapped the calcareous plate onto the colluvial "bed" made of mainly pebbly-sandysilty material; the second stage is represented by the activation of slide-flow movements with shear planes occurring within the colluvial cover and/or in the top levels of the turbidic bedrock; the third stage is represented by a passive transport of the "plate" by the above-mentioned slide-flow phenomena along a gently dipping slope that was jointing the valley bottom at the end of the middle Pleistocene; there, the deposition of the second order alluvial terraces was being completed. The successive phases of valley incision, during the Late Pleistocene and the Holocene, produced erosion processes at the foot of the "plate" and triggered gravitational relaxing of the plate itself. Temporary fluvial damming could be associated with this phenomenon, but it is only possible to recognize the remnants of the landslide body, constituted by fragments of "Scaglia Rossa" limestone (Figure 8a,b). 

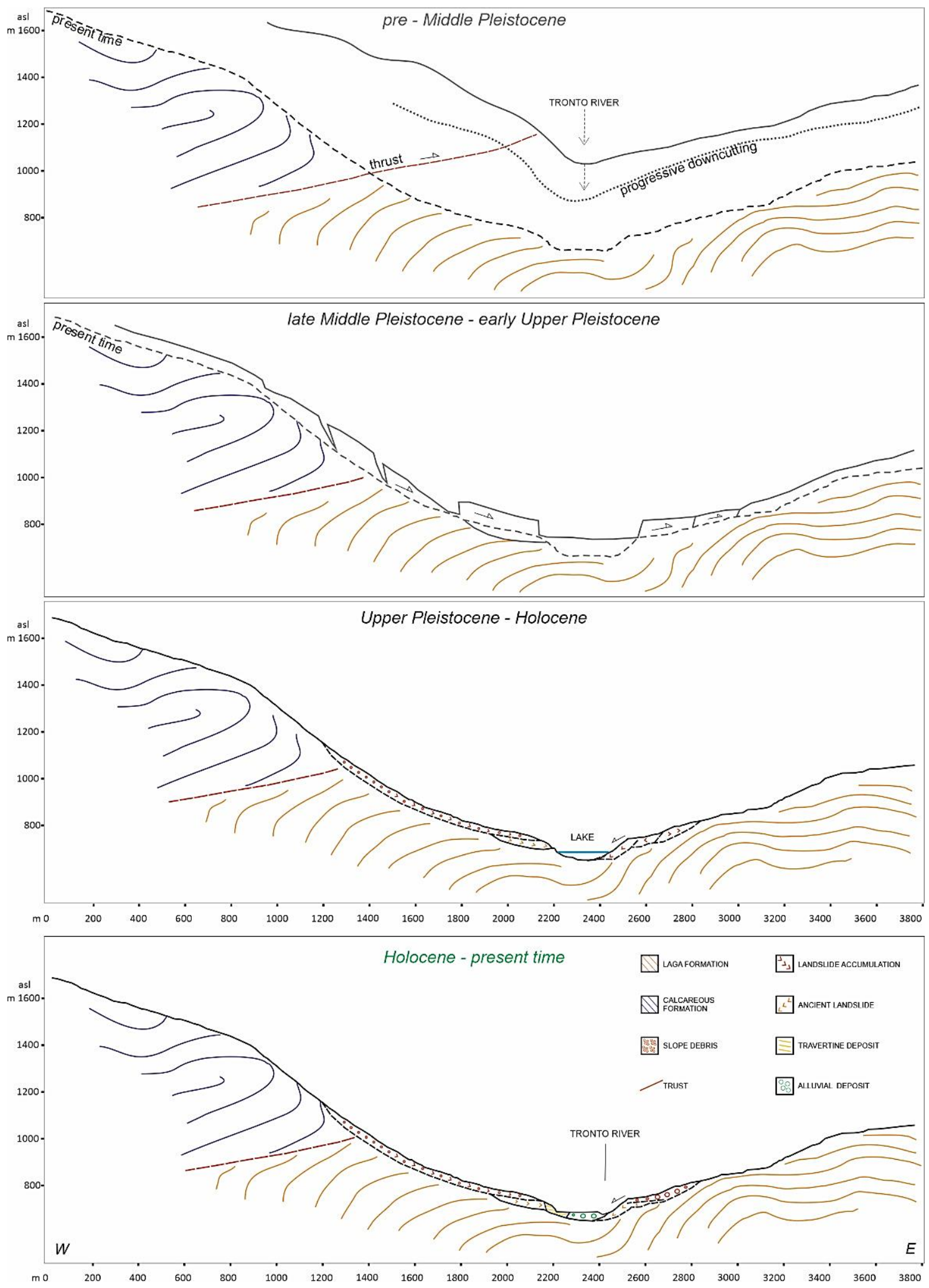

(a)

Figure 8. Cont. 


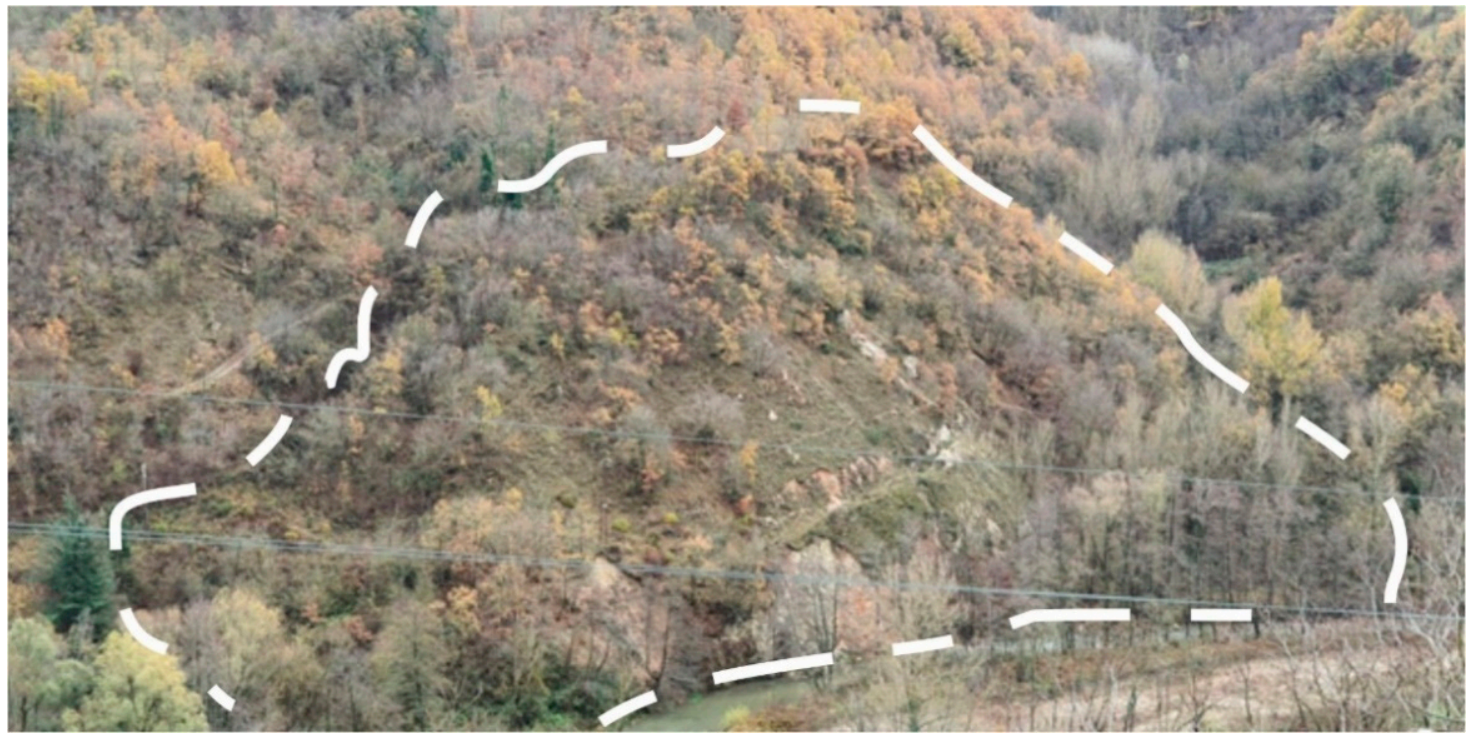

(b)

Figure 8. (a) Evolutionary sketch cross-sections of the Pescara del Tronto landslide (after [10], modified). (b) Remnants (white box) of the ancient body landslide of Pescara del Tronto in the hydrographic right of the Tronto River.

Chronologically it is possible to collocate the phenomena at the end of the midPleistocene; this is demonstrated by the stratified slope deposit of the Late Pleistocene that regularizes the lower portion of the crown and, partially, the third order of alluvial deposits. The main conditioning factors of the mass movement can definitely be recognized: (i) in the intense tectonic fracturing of the rocks, realized both during the building of the compressive structures and during the uplifting and the Pleistocene extensional tectonics; (ii) in the gravitational fracturing, as a result both of the tension release within the calcareous mass following the fluvial erosion of the turbidites below and of the genesis of differential sinking in the same ductile turbidites; (iii) in the high relief; and (iv) in the decay of geomechanical parameters of the calcareous lithotypes related to the genesis of karst levels developed according to the fluvial deepening phases. With regard to activation factors, the following hypothesis is formed. Initial phase was favored by the significant increase of oriented accelerations connected to the intense seismicity of the area and the high-water pressure exercised at the base of the aquifer because it is fed by the endorheic basin of Castelluccio (over $300 \mathrm{~m}$ of difference in height). The following phases were favored by the great quantity of water present on the slope and supplied by numerous springs whose capacity must have been much greater than at present. In fact, in that period, the cataglacial phase at the beginning of Early Pleistocene was ongoing, with consequent dismantling of the glacial systems of the Sibillini Mountains and the great water increase in the aquifers.

\subsection{The Debris Flows Phenomena of Pescara del Tronto}

The geological-stratigraphic setting of the area is rather complex: the bedrock is represented by the lithotypes belonging to the pre-Evaporitic member of the Laga Formation. Slightly above the built-up area of Pescara del Tronto, these lithotypes are in contact, through a very important tectonic-structural element such as the Sibillini Mountains thrust, with the Cretaceous-Eocene calcareous lithotypes (from Maiolica to Scaglia Rossa) of the Umbria-Marche sedimentary sequence [28].

The above-described lithologies are obliterated by continental deposits of different origin. The most ancient sediments of this succession are composed of accumulations of inactive landslides, such as the one located upstream of the inhabited center of Pescara del Tronto, an object, even today, of intense mining activity. Specifically, these deposits are characterized by a chaotic structure and made up of heterogeneous, heterometric elements (also the size of blocks), with sharp edges, both matrix and clast supported, 
naturally stabilized, and locally covered by stratified slope debris attributed to the Late Pleistocene. The higher zone is covered by recent slope deposits, which in part overlap an older stratified phase of deposition (Figures 2 and 9). The colluvial deposits at the foot of the slopes, which often serve as a connection to the valley floor, are also limited in extent.

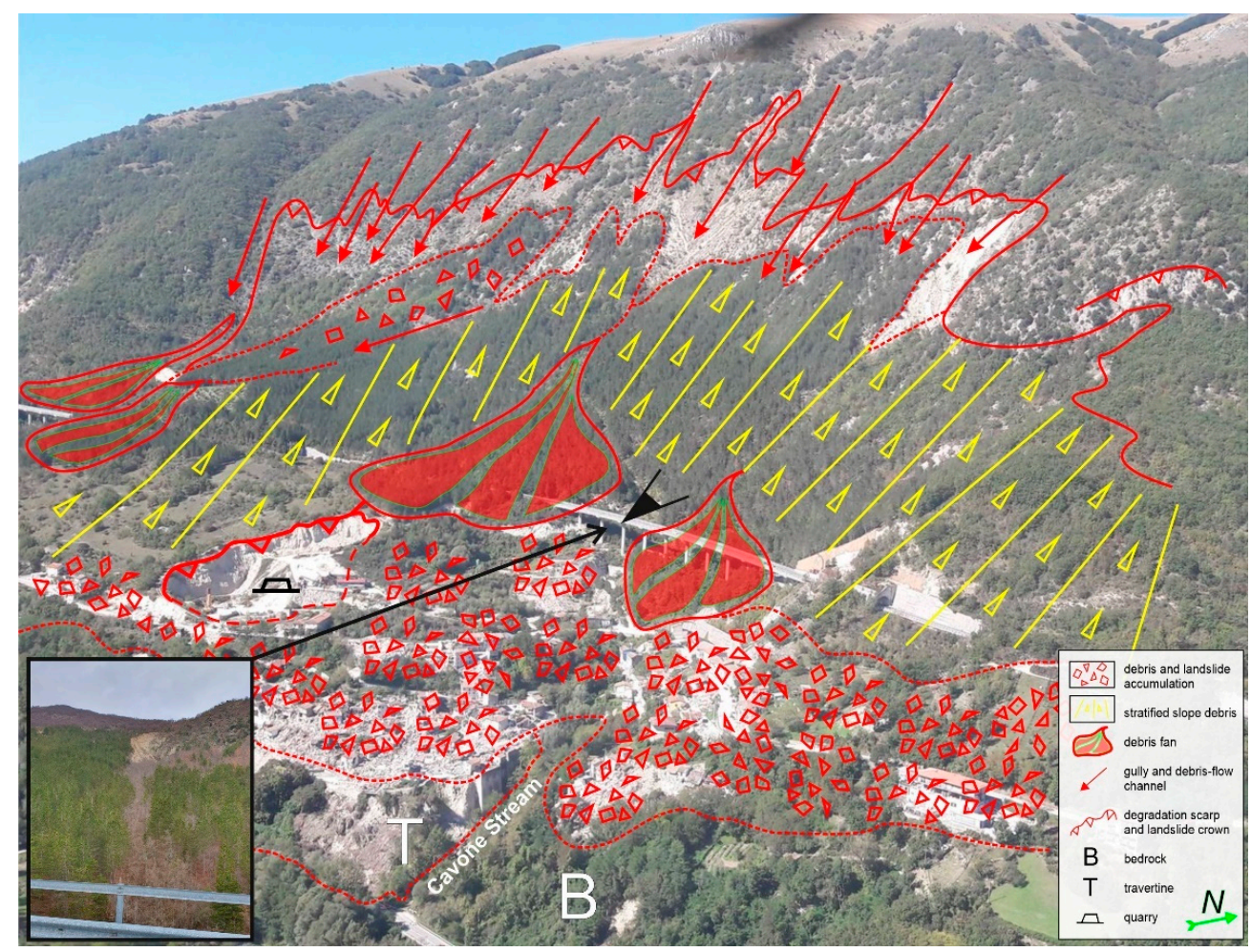

Figure 9. Overview of Pescara del Tronto, the town that was completely destroyed by the seismic events of 24 August and 30 October 2016.

The medium-high sector of the slope upstream of Pescara del Tronto is also crossed by numerous erosion channels filled, in most cases, by debris flow deposits (gravel and subangular polygenic blocks in a silty-sandy matrix). Near the bottom of the valley, gravelly-sandy and sandy-loamy alluvial deposits outcrop, engraved and terraced by the Tronto River (terrace of the first order), which along the current riverbed mainly deposits gravel and sand and subordinately blocks. At the base of the town of Pescara del Tronto and along the valley of the Cavone ditch, travertine deposits emerge in cascade and basin facies and anthropic deposits that are highly heterogeneous and characterized by complex geometrical relationships with the lithotypes present (Figures 2 and 9).

In the southwestern part of the built-up area, there is a quarry used for the extraction of aggregates, with quarry fronts given by steep sub-vertical walls even over twenty meters high. The detritus deposit has a massive structure, except in the central part of the outcrop where it is possible to recognize a pseudo-stratification slightly tilted toward the mountain. The carbonate clasts are heterometric and sharp-edged, from centimeter to meter; the sandy matrix is variable in content, giving the deposit a non-homogeneous texture. The deposit is weakly cemented. At the top of the quarry front there is a paleosoil and above it the debris from the more recent slope. On the upstream side of the built-up area, there is a landslide escarpment set on a deposit made up of intensely cataclasized limestone; the base of the landslide body presents evident consolidation interventions [39].

The debris flows phenomena present dynamics not very different from those of the manure conoids that have shaped many of the wide flat-bottomed valleys within the calcareous Apennines and the area surrounding Mount Vettore, activated on the steep slopes by the conspicuous detritus cover or the regolitic fraction of the rocky substratum. These are extremely rapid processes, generated by the saturation of the debris masses 
by the water which, unlike the fluvial-denudational processes, passively participates in the movement because it is not responsible for the transport of the materials. In fact, the latter do not show any hint of stratification, and their texture is extremely variable (from clays to pebbles to blocks). For historical documentation and "freshness" of the forms, the activity of these processes is placed in the recent Holocene until the beginning of the 20th century $[38,41,60,61]$. In particular, the continuous runoff and debris flows that occurred upstream of the town of Pescara del Tronto forced the Consorzio di Bonifica del Tronto to protect the slope through planting and reforestation, the most important of which was carried out between 1960 and 1972.

\section{Geomorphological Hazard and Resilience}

The aspects related to the geomorphological hazard of large-scale mass movements located along the study area can be summarized in two main points: (1) the possible catastrophic evolution when a stability threshold is overcome, due to natural events and caused by sudden climate variations; (2) the coseismic surface breaks which, similar to the coseismic surface faulting, can affect the territory during important seismic sequences such as that of August 2016 in Central Italy.

The evolution of large-scale landslides characterized by low average slip rates may involve the rapid slide of portions of an unstable slope or the catastrophic movement of entire unstable rock mass $[3,15]$. The main factor hindering the hazard evaluations for large-scale mass movements is due to the difficulty in the estimation of the recurrence time of the single displacement events. Indeed, the activation of the shear planes seems to be episodic, and the subsequent displacements are probably separated by long time intervals $[6,9,62-64]$.

The study area, both for its tectonic-structural conditions and its morpho-evolutive scenario, is very interesting from the perspective of the gravitational phenomena hazard. The vast area is located across slopes including the lines of the overthrust and of the river deepening; these large slopes present very diversified scenarios but of high geomorphological hazard-proceeding from east to west we can verify the presence of different and complex geomorphological situations with increasing hazard conditions.

At the highest altitudes there is, in fact, the DSGSD of Mount Vettoretto [39,55], which in fact could constitute the lowest hazard situation among those analyzed, with the distinctive characteristics of DSGSDs that also in this case manifest its irregular evolution; these, especially during earthquakes of particular intensity, in fact, lead to an increase in the openings of the trenches of the upper portion of the slope. It is clear that the profile, even more convex than normal, favors an intense movement of the slope debris; this accumulates at lower altitudes with a consequent increase in volume of loose rock in the areas of potential triggering of further and different gravitational movements and/or rapid mass processes (debris flows, debris avalanches, falls, etc.).

Going down in altitude, one reaches the Pretare settlement, an area with a lower slope where numerous rocky blocks ("prete" in dialect) are found scattered among the debris accumulations with a smaller grain size and with rare outcrops of the bedrock in place. This area is affected by a high landslide hazard, since there may be a concomitance of various gravitational phenomena, starting in the upper portions of the slope and expanding and accumulating in this valley bottom. These are the aforementioned debris flows but also the collapse/rollover phenomena of large boulders whose areas of influence can involve significantly lower altitudes up to the Pretare village. A further element of hazard is given by these boulders that, once the initial kinematics are exhausted, can continue to move according to a conveyor belt type mechanism and give rise to phenomena similar to lateral-spread $[10,39,41]$.

The geophysical surveys conducted in the settlements of Piedilama and Pretare for the III level of seismic microzonation studies where carried out following the 2016 seismic events (https:/ / sisma2016data.it/microzonazione/); these highlight some areas susceptible to seismic motion amplification, determined by the impedance contrast between the 
accumulation of the "paleolandslide" and the bedrock. Moreover, in this general framework, the variability of the litho-technical characteristics of the bedrock under the two settlements and consisting of thick arenaceous banks within a sub-vertical sequence of pelitic-arenaceous formation, constitutes a further element of hazard [10,39,41].

Going to the west, following the same main valley floor, once the settlement of Piedilama (whose toponym means "at the foot of the landslide") is reached, the scenario is similar to the previous one but with significant variations. It is an area of confluence/accumulation of a greater number of gravitational movements both of flow type (not only debris-flows), and also of sliding type, essentially due to the remobilization of the vast accumulations above. Along the valley floor, being more hydrologically structured (presence of a stable hydrographic network), movements of remobilization of the various materials can also occur due to surface run-off water, which is able to transport mainly the finer granulometries. Finally, it is important to say that, as an area of influence of the collapsing phenomena deriving from the Mount Vettore "walls", due to the major distance this is characterized by less hazard.

The highest hazard levels are found in correspondence with the built-up area of Pescara del Tronto (Figure 9). The geological and morphological evolution of this section of the slope has contributed to the creation of various hydro-geomorphological hazard situations concentrated in a restricted area, which all together delineate a high-risk scenario for the entire zone, both slope and valley floor of the Tronto River [10]. In the highest parts of the slope, the debris layers are gradually thicker and more extensive, sometimes ancient and cemented, and in some cases strongly reincised; these, especially in heavy rainfall conditions and given the considerable dip, facilitate the activation of frequent and great mass transports, such as debris-flow and debris-avalanche [39].

Lower down, the thickness of movable materials increases due to both the dynamics of normal growth along the slope and the coalescence of the various landslide accumulations described above. Numerous water springs are also located in this middle section [10] so that both the morphology of the slope and the considerable emergence of water often cause the above-mentioned deposits to become saturated, a mechanism that in turn leads to the triggering of further and much larger gravitational phenomena of different types and evolutions. In fact, not only further debris-flow movements are triggered from this area but also extensive roto-translational slides that succeed in remobilizing the debris accumulations, sometimes even reaching the main valley floor. It should also be noted that these phenomena are often accompanied by local siphoning and sinking of the various thick accumulations, with triggering of subsidence phenomena.

Finally, at the end of the slope, near the built-up area of Pescara del Tronto, in correspondence with the Covone ditch, travertine deposits are recognizable [39], resulting from carbonate precipitation by the drain waters fed by the basal aquifer of Mount Vettore [10]. This deposit, more than $20 \mathrm{~m}$ thick and attributable to the Upper Pleistocene-Holocene, is composed of phytoclastic and phytohermal lithofacies and of concretions typical of riffle and pool morphologies [65] with very different degrees of cohesion, sometimes mixed with material deriving from debris flows that have characterized this area [39]. The built-up area of Pescara del Tronto rises on these deposits, and it is the different degree of cohesion of these materials to which most of the damage that the village suffered following the 2016-2017 seismic crisis can be precisely attributed.

In addition, these deposits, although of limited extension [39], are often subject to collapse/tilting phenomena that, while collapsing or tilting only a short distance, can strongly interfere with the valley floor dynamics, with the hydrographic network, and with the existing infrastructure system.

Finally, it should be remembered that the seismicity of the area contributes significantly to increasing the already high level of hazard-not only because of the oriented acceleration that reduces the trigger thresholds but also because of the numerous landslides and instabilities that can also occur simultaneously, determining what in the most serious cases is unfortunately already known. 
Therefore, these situations also obligate careful reflection on the modalities that can be implemented to make the population aware of the risk propensity in the inhabited areas and in the territory in general, both to help plan interventions and also to address perceptions of risk $[38,61,66]$ that could consequently increase resilience $[61,67]$.

\section{Discussion and Concluding Remarks}

The present work aimed to contribute to the knowledge on the conditioning of active tectonic structures on the triggering of large landslides or DSGSD in a mountain front, generated by the Quaternary uplift and characterized by the presence of a very important basal aquifer.

Considering the international scientific literature, the studies that have focused on this topic are rare, as we consider the passive role exerted by tectonic structures that, generating strong disarticulation of the bedrock and in conjunction with high relief energy, favors more or less complex gravitational mechanisms. Therefore, as there are few international studies that have the linkage we discuss, the present work can make an important contribution in a poorly understood field that concerns the relationship between important tectonic structures, critical hydrogeological conditions, and high relief energies versus huge gravitational movements.

The first activation and the following evolution of the observed deep gravitational phenomena can be dated only through relative methods, since they do not have any good element of dateability. Particularly useful for this purpose are the relationships between the elements on the deformed slopes (involved in large landslides) and the stratified slope debris deposited in a periglacial environment, the terraced alluvial deposits, the lacustrine deposits, and the moraines.

These different relationships allow us to place the first activation of many phenomena before the last cold phases of the Pleistocene (or, at least, simultaneously with them), and, in many cases, to recognize their reactivations. Only rarely in historical or recent times have these later phenomena been observed, especially under strong earthquakes or extreme precipitations in the terrigenous lithotypes of the Adriatic belt.

Furthermore, the main causes of these complex gravitational movements are to be found in the intense tectonic deformation of the bedrock, which has been folded and overlapped, and in the existence of residual compressive stresses. The recent uplifting with the associated gradients favorable to erosional processes has also facilitated the activation of lateral spreading phenomena, according to the type described by [68]; these mechanisms have given rise to ridge splitting, lateral expansions, and sackungs, mainly along slopes modelled on stratified limestone formations. Additionally, slides (deep-seated block-slide) along pre-existing planes or shear zones or in marly-clayey layers occurred; these have also evolved into further gravitational phenomena, especially at the margins of the large deformed masses.

The variation of the geomechanical parameters relating to the landslide bodies' rocks is a consequence of the displacements due to the internal deformation of the rock mass [69]; it follows that the progressive reduction of the intrinsic shear strength at the base of the rock mass depends on the lithology and its internal structure, on the type and stage of slope evolution, as well as on the presence of water $[2,8,9,70]$. The combination of these factors conditions, in fact, the post-collapse stress-strain behavior of the rocky mass at the considered moment of the slope "history"; therefore, in case of large and complex landslide phenomena, although climatic variations [71] may play a primary role in reducing the recurrence interval between displacement events, the rock mass features may have a minor influence.

Due to the long recurrence intervals in the activity of capable faults, such as the Mount Vettore fault, which has conditioned gravitational movements in the past and still does, the occurrence of catastrophic phenomena may take tens of thousands of years or may not occur if other factors (particularly the climate) have a negligible impact on the evolution of the phenomena. If the long recurrence interval for fault activation can be a reassuring 
factor, the seismic amplification registered on the ground along a fault is a process that can condition the evolution of landslides. Thus, is evident that anomaly amplified seismic waves can accelerate the evolution of instability phenomena in sudden and catastrophic events.

The systematic geomorphological analysis carried out in the study area has made it possible to understand the main genetic factors of surveyed mass movements, which can be summarized as follows:

(a) lithology of the bedrock characterized by high thicknesses of massive limestone rocks or arenaceous formations overlying less resistant marls or thinly stratified levels with pelitic intercalations;

(b) geological structures deriving from compressive tectonics to which is connected the presence of strong residual tensions and shear zones, along which gravitational shifts that may occur on a large scale;

(c) recent strong uplift that has characterized the ridge areas, where the presence of resistant rocks and the river downcutting has given rise to a high relief energy with extended and steep slopes, limited by deep transverse valleys or overthrust fronts;

(d) extensional tectonics that have given rise to high fault scarps that sometimes allowed the outcropping of potential sliding planes along which huge gravitational phenomena have set in;

(e) high seismicity of the area, particularly active along the axes of the chain.

Therefore, the location of many landslides along the seismogenic faults represents a factor that can considerably increase the local hazard related to gravitational phenomena, especially if these are conditioned by an important relief energy.

Author Contributions: Conceptualization, D.A. and P.F.; methodology, D.A. and P.F.; software, D.A. and P.F.; validation, D.A., P.F., M.M. and G.P.; formal analysis, D.A., P.F., M.M., G.P., M.B., E.F. and M.G.; investigation, D.A., P.F. and G.S.; resources, D.A., P.F. and G.P.; data curation, D.A. and P.F.; writing — original draft preparation, D.A. and P.F.; writing-review and editing, D.A. and P.F.; visualization, D.A., P.F., M.M., G.P., M.B., E.F. and M.G.; supervision, D.A., P.F., M.M. and G.P.; project administration, D.A. and P.F.; funding acquisition M.M. and G.P. All authors have read and agreed to the published version of the manuscript.

Funding: This research received no external funding.

Institutional Review Board Statement: Not applicable.

Informed Consent Statement: Not applicable.

Conflicts of Interest: The authors declare no conflict of interest.

Software: All data processing necessary to produce the maps was performed using QGIS (v.3.16). Figures in the document were created using CorelDraw Home\&Student 2019.

\section{References}

1. Gentili, B.; Pambianchi, G. Deep-Seated Gravitational Slope Deformations and Large Landslides in the Central Apennines (F.124 Macerata); Interlinea Editors: Teramo, Italy, 1993.

2. Dramis, F.; Sorriso Valvo, M. Deep seated gravitational slope deformations, related landslides and tectonics. Eng. Geol. 1994, 38, 231-243. [CrossRef]

3. Dramis, F.; Farabollini, P.; Gentili, B.; Pambianchi, G. Neotectonics and large-scale gravitational phenomena in the Umbria-Marche Apennines, Italy. In Steepland Geomorphology; Slaymaker, O., Ed.; J. Wiley \& Sons: Chichester, UK, 1995; pp. $199-217$.

4. Farabollini, P.; Folchi Vici D'Arcevia, C.; Gentili, B.; Luzi, L.; Pambianchi, G.; Viglione, F. The gravitational morphogenesis in central Apennine lithoid formations (in Italian: La morfogenesi gravitativa nelle formazioni litoidi dell'Appennino centrale). Mem. Soc. Geol. It. 1995, 50, 123-136.

5. Coltorti, M.; Farabollini, P.; Gentili, B.; Pambianchi, G. Geomorphological evidence for anti-Apennine faults in the UmbroMarchean Apennines and in the peri-Adriatic basin, Italy. Geomorphology 1996, 15, 33-45. [CrossRef]

6. Dramis, F.; Gentili, B.; Pambianchi, G.; Aringoli, D. The gravitational morphogenesis in the Adriatic side of the Marche region (in Italian: La morfogenesi gravitativa nel versante adriatico marchigiano). Studi Geol. Camerti 2002, 1, 103-125.

7. Di Luzio, E.; Saroli, M.; Esposito, C.; Bianchi-Fasani, G.; Cavinato, G.P.; Scarascia Mugnozza, G. Influence of structural framework on mountain slope deformation in the Maiella anticline (Central Apennines, Italy). Geomorphology 2004, 60, 417-432. [CrossRef] 
8. Martino, S.; Moscatelli, M.; Scarascia Mugnozza, G. Quaternary mass movements controlled by a structurally complex setting in the Central Apennines (Italy). Eng. Geol. 2004, 72, 33-55. [CrossRef]

9. Galadini, F. Quaternary tectonics and large-scale gravitational deformations with evidence of rock-slide displacements in the Central Apennines (central Italy). Geomorphology 2006, 82, 201-228. [CrossRef]

10. Aringoli, D.; Gentili, B.; Materazzi, M.; Pambianchi, G. Mass movements in Adriatic Central Italy: Activation and evolutive control factors. In Landslides: Causes, Types and Effects, 1st ed.; Werner, E.D., Friedman, H.P., Eds.; Nova Science Publisher, Inc.: New York, NY, USA, 2010; pp. 1-71.

11. Kellogg, K.S. Tectonic controls on a large landslide complex: Williams Fork Mountains near Dillon, Colorado. Geomorphology 2001, 41, 355-368. [CrossRef]

12. Ambrosi, C.; Crosta, G.B. Large sackung along major tectonic features in the Central Italian Alps. Eng. Geol. 2006, 83, 183-200. [CrossRef]

13. Hippolyte, J.C.; Brocard, G.; Tardy, M.; Nicoud, G.; Bourlès, D.; Braucher, R.; Ménard, G.; Souffaché, B. The recent fault scarps of the Western Alps (France): Tectonic surface ruptures or gravitational sackung scarps? A combined mapping, geomorphic, levelling, and 10Be dating approach. Tectonophysics 2006, 418, 255-276. [CrossRef]

14. Hradecky, J.; Panek, T. Deep-seated gravitational slope deformations and their influence on consequent mass movements (case studies from the highest part of the Czech Carpathians). Nat. Hazards 2008, 45, 235-253. [CrossRef]

15. Zerathe, S.; Lebourg, T. Evolution stages of large deep-seated landslides at the front of a subalpine meridional chain (MaritimeAlps, France). Geomorphology 2012, 138, 390-403. [CrossRef]

16. Panek, T.; Klimes, J. Temporal behavior of deep-seated gravitational slope deformations: A review. Earth Sci. Rev. 2016, 156, 14-38. [CrossRef]

17. Alfaro, P.; Delgado, J.; Esposito, C.; Tortosa, F.G.; Marmoni, G.M.; Martino, S. Time-dependent modelling of a mountain front retreat due to a fold-to-fault controlled lateral spreading. Tectonophysics 2019, 773, 228233. [CrossRef]

18. Teshebaeva, K.; Echtler, H.; Bookhagen, B.; Strecker, M. Deep-seated gravitational slope deformation (DSGSD) and slowmoving landslides in the southern Tien Shan Mountains: New insights from InSAR, tectonic and geomorphic analysis Kanayim Teshebaeva. Earth Surf. Process. Landforms 2019, 44, 2333-2348. [CrossRef]

19. Varnes, D.J. Slope Movement Types and Processes; Landslides: Analysis and Control (U.S.), National Res. Council, Transportation Res. Board Special Report; National Academy of Sciences: Washington, DC, USA, 1978; Volume 76, pp. 11-33.

20. Centamore, E.; Deiana, G. The Geology of Marches (in Italian: La Geologia delle Marche). Studi Geol. Camerti 1986, $13,9-27$.

21. Centamore, E.; Cantalamessa, G.; Micarelli, A.; Potetti, M.; Berti, D.; Bigi, S.; Morelli, C.; Ridolfi, M. Stratigraphy and facies analysis of Miocene and lower Pliocene deposits of the Marches-Abruzzo foreland and adjacent areas (in Italian: Stratigrafia e analisi di facies dei depositi del Miocene e del Pliocene inferiore dell'avanfossa marchigiano-abruzzese e delle zone limitrofe). Studi Geol. Camerti 1991, 11, 125-131.

22. Centamore, E.; Micarelli, A. Stratigraphy (in Italian: Stratigrafia). In The Physical Environment of the Marches (Italian Version: L'ambiente Fisico delle Marche); S.E.L.C.A.: Florence, Italy, 1991; pp. 5-58.

23. Castellarin, A.; Colacicchi, A.; Praturlon, A. Distensive phases, transcurrences and overthrusts along the "Ancona-Anzio" line from the Middle Lias to the Pliocene (in Italian: Fasi distensive, trascorrenze e sovrascorrimenti lungo la linea "Ancona-Anzio" dal Lias medio al Pliocene). Geol. Romana 1978, 17, 161-189.

24. Calamita, F.; Deiana, G. Correlation between neogeneic-quaternary deformation events in the Tuscan-Umbrian-Marches sector (in Italian: Correlazione tra gli eventi deformativi neogenico-quaternari del settore tosco-umbro-marchigiano). Studi Geol. Camerti 1995, 1, 137-152.

25. Calamita, F.; Coltorti, M.; Farabollini, P.; Pizzi, A. Quaternary normal faults in the Umbria-Marches Apennines Ridge. Proposal of an inversion tectonics model. (in Italian: Le faglie normali quaternarie nella Dorsale appenninica umbro-marchigiana. Proposta di un modello di tettonica d'inversione). Studi Geol. Camerti 1994, 211-225. [CrossRef]

26. Lavecchia, D. The Sibillini Mountains overthrust: Kinematic and structural analysis (in Italian: Il sovrascorrimento dei Monti Sibillini: Analisi cinematica e strutturale). Boll. Soc. Geol. Ital. 1985, 104, 161-194.

27. Cooper, C.J.; Burbi, L. The geology of the central Sibillini mountains. Mem. Soc. Geol. It. 1988, 35, 323-347.

28. Pierantoni, P.P.; Deiana, G.; Galdenzi, S. Stratigraphic and structural features of the Sibillini Mountains (Umbria-Marche Apennines, Italy). Ital. J. Geosci. 2013, 132, 497-520. [CrossRef]

29. Coltorti, M.; Farabollini, P. Quaternary Evolution of the "Castelluccio di Norcia” Basin (Umbro-Marchean Appennines, Central Italy). Il Quat. 1995, 8, 149-166.

30. Aringoli, D.; Cavitolo, P.; Farabollini, P.; Galindo-Zaldivar, J.; Gentili, B.; Giano, S.I.; Lopez-Garrido, A.C.; Materazzi, M.; Nibbi, L.; Pedrera, A.; et al. Morphotectonic characterization of the quaternary intermontane basins of the Umbria-Marche Apennines (Italy). Rend. Lincei 2014, 25, 111-128. [CrossRef]

31. Cello, G.; Mazzoli, S.; Tondi, E.; Turco, E. Active tectonics in the Central Apennines and possible implications for seismic hazard analysis in peninsular Italy. Tectonophysics 1997, 272, 43-68. [CrossRef]

32. Galadini, F; Galli, P. Active tectonics in the Central Apennines (Italy)_Input data for seismic hazard assessment. Nat. Hazards 2000, 22, 225-268. [CrossRef] 
33. Ambrosetti, P.; Carraro, F.; Deiana, G.; Dramis, F. Il sollevamento dell'Italia centrale tra il Pleistocene inferiore ed il Pleistocene medio. In Progetto Finalizzato "Geodinamica", Contributi Conclusivi per la Realizzazione della Carta Neotettonica d'Italia; CNR: Roma, Italy, 1982; Volume 1, pp. 219-223.

34. Dramis, F. The role of wide-range tectonic uplifts in the genesis of the Apennines relief. (in Italian: Il ruolo dei sollevamenti tettonici a largo raggio nella genesi del rilievo appenninico). Studi Geol. Camerti 1992, 1, 9-15.

35. Coltorti, M.; Dramis, F. Geology and Geomorphology of the Sibillini Mountains (in Italian: Geologia e Geomorfologia dei Monti Sibillini); Tecnoprint: Ancona, Italy, 1990; pp. 132-137.

36. Amato, G.; Devoti, R.; Fubelli, G.; Aringoli, D.; Bignami, C.; Galvani, A.; Moro, M.; Polcari, M.; Saroli, M.; Sepe, V.; et al. Step-like displacements of a deep seated gravitational slope deformation observed during the 2016-2017 seismic events in Central Italy. Eng. Geol. 2018, 246, 337-348. [CrossRef]

37. Di Naccio, D.; Kastelic, V.; Carafa, M.M.C.; Esposito, C.; Milillo, P.; Di Lorenzo, C. Gravity versus tectonics: The case of 2016 Amatrice and Norcia (central Italy) earthquakes surface coseismic fractures. J. Geophys. Res. Earth Surf. 2019, 124, 994-1017. [CrossRef]

38. Farabollini, P.; Angelini, S.; Fazzini, M.; Lugeri, F.R.; Scalella, G.; Aringoli, D.; Materazzi, M.; Pambianchi, G. The Central Italy seismic sequence of August 24th and after: Contributions to knowledge and database of surface effects (in italian: La sequenza sismica dell'Italia centrale del 24 agosto e successive: Contributi alla conoscenza e la banca dati degli effetti di superficie). Rend. Online Soc. Geol. It. 2018, 46, 9-15.

39. Farabollini, P.; De Pari, P.; Discenza, M.E.; Minnillo, M.; Carabella, C.; Paglia, G.; Miccadei, E. Geomorphological evidence of debris flows and landslides in the Pescara del Tronto area (Sibillini Mts., Marche Region, Central Italy). J. Map 2020. [CrossRef]

40. Dramis, F.; Maifredi, P.; Sorriso-Valvo, M. Deep-seated gravitational slope deformations. Geomorphological aspects and diffusion in Italy (in Italian: Deformazioni gravitative profonde di versante. Aspetti geomorfologici e loro diffusione in Italia). Geol. Appl. Idrogeol. 1983, 18, 255-268.

41. Gentili, B. Notes on Geomorphology of the Monti Sibillini National Park (in Italian: Note di geomorfologia del Parco Nazionale dei Monti Sibillini); Aniballi Grafiche: Ancona, Italy, 2001; 50p.

42. Folchi Vici, C.; Gentili, B.; Luzi, L.; Pambianchi, G.; Viglione, F. Deep-seated gravitational slope deformation in the central-southern Umbro-Marchean Apennines:,morphometric and macrostructural analysis. Geogr. Fis. Dinam. Quat. 1996, 19, $335-341$.

43. Aringoli, D.; Gentili, B.; Pambianchi, G.; Piscitelli, A.M. The contribution of the 'Sibilla Appenninica' legend to karst knowledge in the Sibillini Mountains (Central Apennines, Italy). Geol. Soc. Lond. Spec. Publ. 2007, 273, 329-340. [CrossRef]

44. Aringoli, D.; Gentili, B.; Materazzi, M.; Pambianchi, G. Deep-seated gravitational slope deformations in active tectonics areas of the umbria-marche apennine (central Italy). Geogr. Fis. Din. Quat. 2010, 33, 127-140.

45. Gentili, B.; Pambianchi, G.; Aringoli, D.; Cilla, G.; Farabollini, P.; Materazzi, M. Relationships between Plio-Quaternary brittle deformation and gravitational morphogenesis in the high hills of central-southern Marche region (in Italian: Rapporti tra deformazioni fragili plio-quaternarie e morfogenesi gravitativa nella fascia alto-collinare delle Marche centro-meridionali). Studi Geol. Camerti 1995, 1, 421-435.

46. Aringoli, D.; Bisci, C.; Blumetti, M.; Buccolini, M.; Ciccacci, S.; Cilla, G.; Coltorti, M.; De Rita, D.; D’Orefice, M.; Dramis, F.; et al. Geomorphology and Quaternary evolution of central Italy. Guide for excursion. Geogr. Fis. Dinam. Quat. 1997, III, 79-103.

47. Zernitz, E.R. Drainage patterns and their significance. J. Geol. 1932, 40, 498-521. [CrossRef]

48. Panizza, M.; Piacente, S. Geomorphological convergence of heterogeneous morphosculptures: Fine-tuning for neotectonics research (in Italian: Convergenza geomorfologica di morfosculture eterogeniche: Messa a punto per ricerche di neotettonica). Gruppo Studio Quat. Padano Torino 1976, 3, 39-44.

49. Catalano, S.; Grassi, S.; Imposa, S.; Lombardo, G.; Panzera, F.; Romagnoli, G.; Tortorici, G. Geological and geophysical evidence of the Pretare-Piedilama normal fault (Arquata del Tronto, Central Italy). In Proceedings of the GNGTS Conference, Lecce, Italy, 22-24 November 2016; pp. 30-33.

50. Tortorici, G.; Romagnoli, G.; Grassi, S.; Imposa, S.; Lombardo, G.; Panzera, F.; Catalano, S. Quaternary negative tectonic inversion along the Sibillini Mts. thrust zone: The Arquata del Tronto case history (Central Italy). Environ. Earth Sci. 2019, 78, 1-12. [CrossRef]

51. Radbruch-Hall, D. Gravitational Creep of Rock Masses on Slopes. Dev. Geotech. Eng. 1978, 14, $607-657$.

52. Chigira, M. Long-term gravitational deformation of rocks by mass rock creep. Eng. Geol. 1992, 32, 157-184. [CrossRef]

53. Gentili, B.; Pambianchi, G. Gravitational morphogenesis of the Apennine chain in central Italy. In Proceedings of the International Congress International Association of Engineering Geology, Lisboa, Portugal, 5-9 September 1994; pp. 1171-1186.

54. Tolomei, C.; Taramelli, A.; Moro, M.; Saroli, M.; Aringoli, D.; Salvi, S. Analysis of the deep-seated gravitational slope deformations over Mt. Frascare (Central Italy) with geomorphological assessment and DInSAR approaches. Geomorphology 2016, 201, 281-292. [CrossRef]

55. Aringoli, D.; Farabollini, P.; Giacopetti, M.; Materazzi, M.; Paggi, S.; Pambianchi, G.; Pierantoni, P.P.; Pistolesi, E.; Pitts, A.; Tondi, E. The August 24th 2016 Accumoli earthquake: Surface faulting and deep-seated gravitational slope deformation (DSGSD) in the Monte Vettore area. Ann. Geophys. 2016, 59. [CrossRef]

56. Aringoli, D.; Gentili, B.; Materazzi, M.; Pambianchi, G.; Sciarra, N. DSGSDs induced by post-glacial decompression in Central Apennine (Italy). Landslide Sci. Pract. Glob. Environ. Chang. 2013, 4, 417-423.

57. Zaruba, Q.; Mencl, V. Landslides and their control. Earth-Sci. Rev. 1969, 6, 205. 
58. Beck, A.C. Gravity faulting as a mechanism of topographic adjustment. N. Z. J. Geol. Geophys. 1968, 11, 191-199. [CrossRef]

59. Nemcok, A. Gravitational slope deformation in high mountains. In Proceedings of the 24th International Geological Congress, Montreal, QC, Canada, 21-30 August 1972; Volume 13, pp. 132-141.

60. Farabollini, P.; Spurio, E. GIS applications in the study of debris flows phenomena in the Umbria-Marches Apennines (Marche region, Italy) (in Italian: Applicazione dei GIS nello studio dei fenomeni di debris flows dell'appennino umbro-marchigiano (regione Marche, Italia)). Rend. Sgi Online 2009, 8, 50-58.

61. Farabollini, P.; Angelini, S.; Fazzini, M.; Lugeri, F.R.; Scalella, G.; Aringoli, D.; Materazzi, M.; Pambianchi, G. Earthquakes and Society: The 2016 Central Italy Reverse Seismic Sequence. In Earthquake Risk Perception, Communication and Mitigation Strategies across EUROPE, Geographies of the Anthropocene; Farabollini, P., Lugeri, F.R., Mugnano, S., Eds.; Il Sileno Edizioni: Lago, Italy, 2019; pp. 249-266. ISSN 2611-3171.

62. Sorriso-Valvo, M. Studies on deep-seated gravitational slope deformations in Italy (in Italian: Studi sulle deformazioni gravitative profonde di versante in Italia). Mem. Soc. Geol. It. 1988, 41, 877-888.

63. Petley, D. Landslide Hazards. Geomorphological Hazards and Disaster Prevention; Cambridge University Press: Cambridge, UK, 2010; pp. 63-73.

64. Arai, N.; Chigira, M. Distribution of gravitational slope deformations and deep-seated landslides controlled by thrust faults in the Shimanto accretionary complex. Eng. Geol. 2019, 260, 105236. [CrossRef]

65. Farabollini, P.; Materazzi, M.; Miccadei, M.; Piacentini, T. The travertines of Central Adriatic Italy: Genesis, chronology, and geomorphological and paleoenvironmental significance (in Italian: I travertini dell'Italia centrale adriatica: Genesi, cronologia e significato geomorfologico e paleoambientale). Il Quat. 2004, 17, 259-272.

66. Lugeri, F.R.; Farabollini, P. Landscape analysis as a tool for risk reduction. Aims Geosci. 2019, 5, 617-630. [CrossRef]

67. Farabollini, P. The 2016 Earthquake in Central Italy. The alphabet of reconstruction. In Earthquake Risk Perception, Communication and Mitigation Strategies across Europe; Farabollini, P., Lugeri, F.R., Mugnano, S., Eds.; Geographies of the Anthropocene Book Series; Sileno Edizioni: Lago, Italy, 2019; Volume 2, pp. 145-171.

68. Jahn, A. Slope morphological features resulting from gravitation. Zeit. Geomorph. 1964, 5, 59-72.

69. Hoek, E.; Bray, J. Rock Slope Engineering, 3rd ed.; Institution Mining and Metallurgy: London, UK, 1981.

70. Esposito, E.; Martino, S.; Scarascia Mugnozza, G. Mountain slope deformations along thrust fronts in jointed limestone: An equivalent continuum modelling approach. Geomorphology 2007, 90, 55-72. [CrossRef]

71. Aringoli, D.; Farabollini, P.; Gentili, B.; Materazzi, M.; Pambianchi, G. Climatic influence on slope dynamics and shoreline variations: Examples from Marche region (Central Italy). Physio-Géo Géogr. Phys. Environ. 2007, 1, 1-20. [CrossRef] 